\title{
Epidemiological Pattern of Road Traffic Injuries among Occupants' Vehicles in 2012
}

\section{Elaheh Ainy¹, Ali Khorshidi' ${ }^{2}$, Ayad Bahadori Monfared ${ }^{3}$, Hamid Soori' ${ }^{1}$ Mashyaneh Haddadi1,4*}

${ }^{1}$ Safety Promotion and Injury Prevention Research Center, Deputy Research Department, Shahid Beheshti University of Medical Sciences, Tehran, Iran

${ }^{2}$ Department of Epidemiology, Ilam University of Medical Sciences, Ilam, Iran

${ }^{3}$ Social Medicine Department, Shahid Beheshti University of Medical Sciences, Tehran, Iran

${ }^{4}$ Injury Prevention and Safety Promotion Department, Disaster and Emergency Management Center, Ministry of Health and Medical

Education, Tehran, IRran

Email: ainy.elaheh@gmail.com, ali_482002@yahoo.com,dr.a.bahadori@gmail.com, hsoori@yahoo.com, ^mashyaneh_hd@yahoo.com

How to cite this paper: Ainy, E., Khorshidi, A., Monfared, A.B., Soori, H. and Haddadi, M. (2016) Epidemiological Pattern of Road Traffic Injuries among Occupants' Vehicles in 2012. Journal of Transportation Technologies, 6, 277-285.

http://dx.doi.org/10.4236/jtts.2016.65025

Received: July 11, 2016

Accepted: September 25, 2016

Published: September 28, 2016

Copyright $\odot 2016$ by authors and Scientific Research Publishing Inc. This work is licensed under the Creative Commons Attribution International License (CC BY 4.0).

http://creativecommons.org/licenses/by/4.0/

(c) (i) Open Access

\begin{abstract}
There has been no precise information regarding occupants' status and their portion in traffic accident. By using traffic police information, epidemiological pattern of road traffic injuries among occupants' vehicles was analyzed in 2012. It was a cross sectional study. In this study, traffic police registered data in 2012 were used. Subjects were all occupants who had accident record in 2012 (81585: 77841 injured and 3744 death). Before analyzing, various preparatory steps including data control and merging were done after which data were processed. Findings showed that the mean age of the studied population was $28.7 \pm 15.11$ years. The highest percentage of accident occurred among car and motorcycle occupants respectively. The risk of death among the injured aged $30-59$ years and $60+$ were 1.20 and 2.23 times more than 30 years (as reference) respectively $(\mathrm{p}<0.001)$. Risk of death among the injured in high ways, main roads and rural roads was 2.84 times more than in urban roads ( $\mathrm{p}<$ 0.001 ). The risk of death among the injured was 2 times higher in high ways, main roads and rural secondary roads than streets $(\mathrm{p}<0.001)$. Hence car and motorcycle occupants need urgent attention especially in motorways and high ways, main roads and rural secondary.
\end{abstract}

\section{Keywords}

Occupant, Injured, Death, Motor Ways, High Ways, Main Roads, Rural Roads 


\section{Introduction}

Each year about 1.24 million people are killed in road traffic injury [1]. Road traffic injuries (RTIs) are the second leading cause of mortality in Iran. One study which was conducted in Iran in 2001 showed that $79 \%$ of traffic injuries occurred among men of 40 years old range. The share of occupants and passenger were 62\% [2]. Hydari et al.'s study to clarify the main characteristics of motorcycle victims in Fars Province, Iran showed head injury was more prevalent than the other injuries. These patterns were associated with weak enforcement and low socioeconomic status and little education of motorcyclists as one of the vehicle occupants [3]. 1185 victims of road accidents have been studied by Ghadipasha et al. The morbidity and mortality caused by head injury was high and the reason may be traumatic brain injury or delay in diagnosis procedure. It looked that epidemiological data on road accidents were inadequate [4]. In 19872002, traffic injuries caused $25 \%$ of child death in America. $75 \%$ of road traffic death among children less than 14 years occurred up to 4 kilometers from the home. Road traffic death occurred in $60 \%$ of cases in the roads at speed less than $70 \mathrm{~km} / \mathrm{h}$ [5]. Studies showed that among road traffic death, more than 120,000 people were occupants [6] [7]. In 2004, findings from one study conducted in America showed that among road traffic injury victims, 141 people were killed with air bag. Road traffic death cost among children under 14 years was 17.8 billion dollars. Road traffic injuries was more in rural than in urban area. Children who were sitting in the front seat were more prone to death. Fifty three percent of children did not use child restraint or seat belt. Child restraint usage was less in rural than in urban areas. Payment for child restraint is $\$ 45$ which leads to $\$ 1800$ profit for the society [8]. The findings of a study showed that the death rate among occupants, pedestrians and cyclists were 12.7, 1.6 and 0.3 per 100,000 populations [9]. There is no detailed information regarding occupants' status and their contribution to road traffic injuries in Iran which is crucial for evidence based policy making. In this study, traffic police registered information, time, place and person dimensions as component of epidemiological pattern in 2012 were analyzed to present epidemiological pattern of road traffic injuries among occupants' vehicles. The results as a reliable reference could be available for use by stakeholders in road traffic injury planning and policy making.

\section{Methods}

After taking Shahid Beheshti Uinversity of Medical Sciences Ethical Committee approval to the study, all police records for RTIs (81585: 77841 injured and 3744 death) in 2012 were investigated. RTI data was collected daily by the police at accident scenes using an advanced data registry system. Statistical analysis was performed using STATA (version 12.0) software. All accidents in which at least one passenger was injured was studied. During data controlling all duplicated and missing data were excluded. Demographic variables: gender, age, education, type of outcome, situation of accident was analyzed. Descriptive analysis of occupants' traffic injuries and death was performed. The presentation of the percentage of categorical variables and mean and standard 
deviation were used for quantitative variables. Using logistic regression model to calculate the probability of death resulting to non-fatal injuries for the studied variables in occupants were used in two ways: univariate and multivariate. Odds ratios and $95 \%$ confidence interval was reported.

\section{Results}

Mean age of the subjects was $28.7 \pm 15.11$ years old. Mean age of the men and women were $26.9 \pm 14.3$ and $31.2 \pm 15.8$ years old, respectively.

Table 1 shows the risk of death which was estimated for some of demographic and

Table 1. The effect of demographic and accidental specification variables on risk of death using univariate analysis.

\begin{tabular}{|c|c|c|c|c|c|}
\hline & & \multicolumn{4}{|c|}{ Crude } \\
\hline & & OR & $P$ value & & \\
\hline \multirow{3}{*}{ Sex } & Female & 1.00 & - & - & - \\
\hline & Male & 0.95 & 0.156 & 0.88 & 1.02 \\
\hline & $<30$ & 1.00 & - & - & - \\
\hline \multirow[t]{2}{*}{ Age } & $30-59$ & 1.50 & 0.000 & 1.37 & 1.63 \\
\hline & $60+$ & 2.52 & 0.000 & 2.20 & 2.87 \\
\hline \multirow[t]{3}{*}{ Education } & Illiterate & 1.00 & - & - & - \\
\hline & 12 years education \& lower & 0.56 & 0.000 & 0.48 & 0.67 \\
\hline & Bachelor \& higher & 0.60 & 0.024 & 0.39 & 0.94 \\
\hline \multirow[t]{3}{*}{ Impact location } & Lower limbs & 1.00 & - & - & - \\
\hline & Head and neck & 11.73 & 0.000 & 6.63 & 20.76 \\
\hline & Chest and abdomen & 5.02 & 0.000 & 2.50 & 10.08 \\
\hline \multirow[t]{4}{*}{ Driver's error } & No error & 1.00 & - & - & - \\
\hline & Harried driving & 1.06 & 0.302 & 0.95 & 1.19 \\
\hline & Ignoring regulations & 1.65 & 0.000 & 1.42 & 1.91 \\
\hline & Sleepiness/tiredness & 3.77 & 0.000 & 3.25 & 4.37 \\
\hline \multicolumn{6}{|l|}{ Location } \\
\hline & Urban ways & 1.00 & - & - & - \\
\hline & Motor ways, high ways, rural ways & 9.06 & 0.000 & 8.02 & 10.23 \\
\hline \multicolumn{6}{|l|}{ Weather condition } \\
\hline & Fine & 1.00 & - & - & - \\
\hline & Rainy or snowy & 1.71 & 0.000 & 1.44 & 2.04 \\
\hline \multirow[t]{4}{*}{ Light status } & Day time & 1.00 & - & - & - \\
\hline & Night time & 0.97 & 0.501 & 0.89 & 1.06 \\
\hline & Sunrise & 3.03 & 0.000 & 2.29 & 4.00 \\
\hline & Sunset & 0.72 & 0.021 & 0.55 & 0.95 \\
\hline \multicolumn{6}{|l|}{ Impact } \\
\hline & Side to side & 1.00 & - & - & - \\
\hline & Head on & 4.06 & 0.000 & 3.41 & 4.83 \\
\hline & Rear impact & 1.43 & 0.000 & 1.19 & 1.72 \\
\hline & On fixed object & 2.64 & 0.000 & 1.98 & 3.53 \\
\hline \multicolumn{6}{|l|}{ Road type } \\
\hline & Street & 1.00 & - & - & - \\
\hline & Highway & 9.33 & 0.000 & 7.94 & 10.98 \\
\hline & Main road & 10.90 & 0.000 & 9.36 & 12.69 \\
\hline & Rural secondary road & 9.32 & 0.000 & 7.93 & 10.94 \\
\hline
\end{tabular}


accidental specification using logistic regression model. Results of univariate analysis showed among studied variables the effect of variables on death except gender was significant (Table 1). Table 2 shows that the highest percent of injury was observed in semi-heavy vehicle such as car $(57.30 \%)$ and motorcycle (28.91\%) occupants respectively. The highest percent of death among semi-heavy vehicle car occupants was $66.30 \%$ too (Table 2). Table 3 shows the adjusted odds ratio (OR) for related risk factors after controlling effect of other causes. In comparison to univariate analysis the effect of some of variables on death of injured was not significant. Based on findings the risk of death among injured 30 - 59 years and 60 years and over was 1.20 and 2.23 times more than 30 years (as reference) respectively. The risk of death among illiterate victims was $31 \%$ higher than ones with 12 years education. Risk of death among head and neck and chest injury in comparison to lower limb injury was 5.34 and 2.35 respectively. Risk of death among injured in motor ways, high ways and rural roads was 2.84 times more than in urban roads. Also in rainy and snowy condition risk of death was 3.16 times among injured. Risk of death among occupants in face to face accident was higher than other kind of accidents. So the risk of death for injured was 2 times higher than side to side accident. The risk of death among injured was 2 times higher in high ways, main roads and rural secondary roads than urban roads (Table 3 ).

\section{Discussion}

Among all vehicles, car (semi-heavy vehicle) and motorcyclist (light vehicle) occupants

Table 2. Distribution of kind of accident by light, semi-heavy and heavy vehicles in 2012.

\begin{tabular}{ccc}
\hline Kind of vehicle & \multicolumn{2}{c}{ Number (\%) } \\
\cline { 2 - 3 } & Injury & Death \\
\hline Light & $79(0.10)$ & $1(0.03)$ \\
Bicycle & $22503(28.91)$ & $347(9.27)$ \\
Motorcycle & & \\
Semi-heavy & $44601(57.30)$ & $2482(66.30)$ \\
Car & $1454(1.87)$ & $35(0.93)$ \\
Taxi & $4581(5.88)$ & $368(9.82)$ \\
Van & $858(1.10)$ & $57(1.52)$ \\
Mini Bus & & $1(0.03)$ \\
Heavy & $40(0.05)$ & $203(5.42)$ \\
Ambulance & $1723(2.21)$ & $23(0.61)$ \\
Bus & $74(0.09)$ & $223(6.22)$ \\
Agriculture & $1915(2.46)$ & $4(0.11)$ \\
Truck & $13(0.02)$ & $3744(100)$ \\
Other & $77841(100)$ & \\
Total & &
\end{tabular}


Table 3. The effect of demographic and accidental specification variables on risk of death using multivariate analysis.

\begin{tabular}{|c|c|c|c|c|}
\hline & & OR & & \\
\hline \multirow{2}{*}{ Sex } & Female & 1.00 & - & - \\
\hline & Male & 0.92 & 0.79 & 1.07 \\
\hline \multirow{3}{*}{ Age } & $<30$ & 1.00 & - & - \\
\hline & $30-59^{*}$ & 1.20 & 1.02 & 1.41 \\
\hline & $60+^{* *}$ & 2.23 & 1.74 & 2.85 \\
\hline \multicolumn{5}{|l|}{ Education } \\
\hline & Illiterate & 1.00 & - & - \\
\hline & 12 years education $\&$ lower & 0.69 & 0.55 & 0.86 \\
\hline & Bachelor \& higher & 1.09 & 0.66 & 1.76 \\
\hline \multicolumn{5}{|l|}{ Impact location } \\
\hline & Lower limbs & 1.00 & - & - \\
\hline & Head and neck ${ }^{* *}$ & 5.34 & 2.64 & 10.77 \\
\hline & Chest and abdomen* & 2.35 & 0.96 & 5.75 \\
\hline \multirow[t]{4}{*}{ Driver's error } & No error & 1.00 & - & - \\
\hline & Harried driving & 0.82 & 0.66 & 1.03 \\
\hline & Ignoring regulations & 1.21 & 0.94 & 1.55 \\
\hline & Sleepiness/tiredness & 1.18 & 0.88 & 1.59 \\
\hline \multirow[t]{2}{*}{ Location } & Urban Ways & 1.00 & - & - \\
\hline & Motor ways, high ways, rural ways ${ }^{\star \star}$ & 2.84 & 2.00 & 4.05 \\
\hline \multicolumn{5}{|l|}{ Weather condition } \\
\hline & Fine & 1.00 & - & - \\
\hline & Rainy or snowy & 3.16 & 2.32 & 4.29 \\
\hline \multicolumn{5}{|l|}{ Light status } \\
\hline & Day time & 1.00 & - & - \\
\hline & Night time & 0.95 & 0.81 & 1.12 \\
\hline & Sunrise & 1.39 & 0.80 & 2.40 \\
\hline & Sunset & 0.95 & 1.52 & \\
\hline \multicolumn{5}{|l|}{ Impact } \\
\hline & Side to side & 1.00 & - & - \\
\hline & Head on ${ }^{* *}$ & 2.25 & 1.66 & 3.04 \\
\hline & Rear impact & 1.12 & 0.81 & 1.55 \\
\hline & On fixed object & 1.48 & 0.89 & 2.48 \\
\hline \multicolumn{5}{|l|}{ Road type } \\
\hline & Street & 1.00 & - & - \\
\hline & Highway ** & 2.24 & 1.48 & 3.42 \\
\hline & Main $\operatorname{road}^{\star *}$ & 2.75 & 1.83 & 4.13 \\
\hline & Rural secondary road ${ }^{* *}$ & 2.17 & 1.43 & 3.30 \\
\hline
\end{tabular}

${ }^{*} \mathrm{p}<0.05,{ }^{* *} \mathrm{p}<0.001$ 
were more injured. The risk of death was higher among injured 30 years and over, in motor ways and high ways, main roads and rural secondary. Results of a study on death caused by road traffic injury showed that $79 \%$ of death occurred among men in the age range of 40 years, $62 \%$ of them were occupants and pedestrian [2]. In line with current study Zangooei et al study findings identified fatal accident among all road user groups considering age, gender and head injury on deaths by age and gender at accident scenes. The ages of $21-30$ among pedestrian, motorcyclist and motor vehicle occupant had a surging at fatality. Head injury was more prevalent too. Finding showed the most death occurred at scene among pedestrians aged 21 - 30, motorcyclists 41 - 50 and motor vehicle occupants 31 - 40 (10). Results from the American transport department study showed that among road traffic injury victims, 141 people were killed by air bag. In rural areas, road traffic injury was more and severe than in urban areas [10] [11]. The cost of injury and death caused by road traffic injuries among Iranian occupants were 587 and 451 million dollars, respectively [11]. The World Health Organization in its global report of road safety 2013 announced that the share of road users in Iran was: $28 \%$ passenger, $23 \%$ motorcyclist, $26 \%$ occupants and $23 \%$ drivers [12]. The study showed that car and motorcycle occupants were more injured than other road users. In other studies, pedestrians and motorcyclists were more vulnerable than others [13]-[15]. The World Report on Road Traffic Injury Prevention, published by the World Health Organization and the World Bank, states that road traffic crashes result in at least 1.2 million deaths and over 50 million injuries each year, that road traffic deaths and injuries are forecast to increase by more than $65 \%$ by 2020 . Road traffic injury prevention was considered as prioritizing prevention programs. Among road users, occupants are also included [16] [17]. The study showed that the highest percent of injury occurred in car and motorcycle occupants and the highest percent of death were observed in car occupants. Other studies also showed that car and motorcycle occupants were more vulnerable road users [18]-[20]. The study showed risk of death was higher among injured 30 years and over, in motor ways and high ways, main roads and rural secondary. Suriyawongpaisal et al showed that a higher rural case-fatality rate was observed in comparison to urban areas [21]. Chang et al showed that there was the relationship between injury severity and driver/vehicle characteristics, highway/environmental variables and accidental specification variables. The most important variable associated with injury intensity was, pedestrians, motorcycle riders have higher risks of injury than other types of vehicle drivers.

The finding was in line with results from Chang's study [22]. The study showed that the highest percent of injury and death was observed in rainy or snowy weather condition. Other studies showed that rainy weather, mountainous area and other land users have the same effect on injury and death occurrence [23]-[25].

Reducing the road traffic injuries requires that increased attention be paid to improving the safety of occupants, cyclists and motorcyclists. Fifty percent of all road traffic deaths occur among these road users. Governments and policy making must focus on safety and mobility of these more vulnerable road users, and their safer transport 
systems [26]. Hence policy makers should modify regulations in the event of occupants' safety as a priority. It seems that the public has to be more educated on seat belt usage in line with risk. In this study the rate of injury and death was high on the main roads. Intelligent system is necessary equipment in a country's major roads monitoring and custodians must consider its significance in road traffic injury prevention planning. Large volume of information could be the strength of the study. Data was collected at the scene, with some of information being incomplete. This deficiency could be considered as limitation of the study.

\section{Conclusion}

Among all vehicles, car (as a semi-heavy vehicle) and motorcycle (as a light vehicle) occupants were more injured. Hence car occupants and motorcyclist need urgent attention especially in motor ways and high ways, main roads and rural secondary because they are more vulnerable than other road users.

\section{Acknowledgements}

All authors willing to express their gratitude to Safety Promotion and injury prevention research center of Shahid Beheshti University of Medical Sciences to scientific advices.

\section{Conflict of Interest}

There is no conflict of interest.

\section{Funding Support}

Nil.

\section{Authors Contribution}

Elaheh Ainy, design, monitoring, data gathering, analysis and manuscript writing. Hamid Soori, design, monitoring data gathering, analysis and manuscript writing; Ali Khorshidi, analysis and manuscript writing; Ayad Bahadori Monfared, design and manuscript writing; Mashyaneh Haddadi, design, monitoring data gathering, analysis and manuscript writing.

\section{References}

[1] World Health Organization (2013) Pedestrian Safety: A Road Safety Manual for Decision-Makers and Practitioners.

[2] Montazeri, A. (2004) Road-Traffic-Related Mortality in Iran: A Descriptive Study. Public health, 118, 110-113. http://dx.doi.org/10.1016/S0033-3506(03)00173-2

[3] Heydari, S.T., Hoseinzadeh, A., Ghaffarpasand, F., et al. (2013) Epidemiological Characteristics of Fatal Traffic Accidents in Fars Province, Iran: A Community-Based Survey. Public health, 127, 704-709. http://dx.doi.org/10.1016/j.puhe.2013.05.003

[4] Ghadipasha, M., Vaghefi, S.S., Esfeh, S.K., Teimoori, M., Ouhadi, A.R. and Mirhosseini, S.M. (2015) An Annual Analysis of Clinical Diagnosis versus Autopsy Findings in Fatal 
Motor Vehicle Accident in Legal Medicine Organization of Kerman Province, Iran. Journal of Forensic and Legal Medicine, 34, 164-167. http://dx.doi.org/10.1016/j.jflm.2015.05.013

[5] Driving, R.A.I. (2001) Motor-Vehicle Occupant Injury: Strategies for Increasing Use of Child Safety Seats, Increasing Use of Safety Belts, and Reducing Alcohol-Impaired Driving. MMWR. Recommendations and Reports, 50, 1-13.

[6] Martinez, R. (1997) Traffic Safety Facts (1996): A Compilation of Motor Vehicle Crash Data from the Fatality Analysis Reporting System and the General Estimates System. DIANE Publishing, USA.

[7] Facts, T.S. (2003) A Compilation of Motor Vehicle Crash Data from the Fatality Analysis Reporting System and the General Estimates System. National Highway Traffic Safety Administration. DOT HS, 809, 775.

[8] Fhwa, U. (2006) Status of the Nation's Highways, Bridges, and Transit: Conditions and Performance. US Department of Transportation.

[9] Li, G., Braver, E.R. and Chen, L.H. (2003) Fragility versus Excessive Crash Involvement as Determinants of High Death Rates per Vehicle-Mile of Travel among Older Drivers. Accident Analysis \& Prevention, 35, 227-235. http://dx.doi.org/10.1016/S0001-4575(01)00107-5

[10] Zangooei Dovom, H., Shafahi, Y. and Zangooei Dovom, M. (2013) Fatal Accident Distribution by Age, Gender and Head Injury, and Death Probability at Accident Scene in Mashhad, Iran, 2006-2009. International Journal of Injury Control and Safety Promotion, 20, 121-133. http://dx.doi.org/10.1080/17457300.2012.692694

[11] Ainy, E., Soori, H., Ganjali, M., Le, H., and Baghfalaki, T. (2014) Estimating Cost of Road Traffic Injuries in Iran Using Willingness to Pay (WTP) Method. PLoS ONE, 9, e112721. http://dx.doi.org/10.1371/journal.pone.0112721

[12] Smith, K.M. and Cummings, P. (2006) Passenger Seating Position and the Risk of Passenger Death in Traffic Crashes: A Matched Cohort Study. Injury Prevention, 12, 83-86. http://dx.doi.org/10.1136/ip.2005.010306

[13] Dandona, R., Kumar, G.A., Raj, T.S. and Dandona, L. (2006) Patterns of Road Traffic Injuries in a Vulnerable Population in Hyderabad, India. Injury Prevention, 12, 183-188. http://dx.doi.org/10.1136/ip.2005.010728

[14] Zimmerman, K., Mzige, A.A., Kibatala, P.L., Museru, L.M. and Guerrero, A. (2012) Road Traffic Injury Incidence and Crash Characteristics in Dar es Salaam: A Population Based Study. Accident Analysis \& Prevention, 45, 204-210. http://dx.doi.org/10.1016/j.aap.2011.06.018

[15] Nantulya, V.M. and Reich, M.R. (2002) The Neglected Epidemic: Road Traffic Injuries in Developing Countries. British Medical Journal, 324, 1139. http://dx.doi.org/10.1136/bmj.324.7346.1139

[16] Peden, M. (2004) World Report on Road Traffic Injury Prevention. World Health Organization, Geneva.

[17] World Health Organization (2009) Global Status Report on Road Safety: Time for Action. World Health Organization, Geneva.

[18] Ramage-Morin, P.L. (2008) Motor Vehicle Accident Deaths, 1979 to 2004. Health Reports, $19,45$.

[19] Assembly, U.G. (2005) Improving Global Road Safety. RES/60/5.

[20] Svilanović, G. (2008) The Pan-European Perspective for the Economic Integration of SouthEastern Europe: The Role of the United Nations Economic Commission for Europe. PAN, 2008.

[21] Suriyawongpaisal, P. and Kanchanasut, S. (2003) Road Traffic Injuries in Thailand: Trends, 
Selected Underlying Determinants and Status of Intervention. Injury Control and Safety Promotion, 10, 95-104. http://dx.doi.org/10.1076/icsp.10.1.95.14110

[22] Chang, L.Y. and Wang, H.W. (2006) Analysis of Traffic Injury Severity: An Application of Non-Parametric Classification Tree Techniques. Accident Analysis \& Prevention, 38, 10191027. http://dx.doi.org/10.1016/j.aap.2006.04.009

[23] Norrman, J., Eriksson, M. and Lindqvist, S. (2000) Relationships between Road Slipperiness, Traffic Accident Risk and Winter Road Maintenance Activity. Climate Research, 15, 185-193. http://dx.doi.org/10.3354/cr015185

[24] Brodsky, H. and Hakkert, A.S. (1988) Risk of a Road Accident in Rainy Weather. Accident Analysis \& Prevention, 20, 161-176. http://dx.doi.org/10.1016/0001-4575(88)90001-2

[25] Maheshwari, J. and Mohan, D. (1989) Road Traffic Injuries in Delhi: A Hospital Based Study. Journal of Traffic Medicine, 17, No. 3-4.

[26] Global Status Report on Road Safety 2013: Supporting a Decade of Action. World Health Organization, Geneva.

\section{Submit or recommend next manuscript to SCIRP and we will provide best service} for you:

Accepting pre-submission inquiries through Email, Facebook, LinkedIn, Twitter, etc.

A wide selection of journals (inclusive of 9 subjects, more than 200 journals)

Providing 24-hour high-quality service

User-friendly online submission system

Fair and swift peer-review system

Efficient typesetting and proofreading procedure

Display of the result of downloads and visits, as well as the number of cited articles

Maximum dissemination of your research work

Submit your manuscript at: http://papersubmission.scirp.org/

Or contact jtts@scirp.org 